Original Article

\title{
Aspects related to the permanence of undergraduate and graduate students in semi-presential classes*
}

\author{
Aspectos relacionados à permanência de graduandos e pós-graduandos em disciplinas semipresenciais \\ Aspectos relativos a la estancia de los estudiantes universitarios y de pos graduación en disciplinas \\ semipresenciales
}

\author{
Henry Maia Peixoto', Mariana Maia Peixoto $^{2}$, Elioenai Dornelles Alves ${ }^{3}$
}

\begin{abstract}
Objective: To evaluate the learning and interaction environment, related to the permanence of undergraduate and graduate students in semipresential healthcare classes. Methods: Research of quantitative approach, exploratory, which analyzed data originated, based on a validated questionnaire, based on models ISAM and MAIWT with 18 items, organized in a scale that ranged from zero (hindered my permanence in the class) to 10 (did not hindered my permanence in class). We invited all 220 undergraduate and graduate students finishing classes of their courses in the Faculty of Health Sciences at UNB, of which 148 (67.3\%) students agreed to participate. Results: All 18 items (100\%) answered by undergraduates and $17(94.5 \%)$ by the graduate students presented mean above seven, demonstrating that the use of the virtual environment, the flexibility of time and space, the costs involved, the use of computational tools and procedures for interaction, have been well evaluated. Conclusion: Undergraduate and graduate students considered that the questions related to the study environment and interaction procedures facilitated the permanence in classes.
\end{abstract}

Keywords: Education, distance; Education, higher; Student dropouts; Ambient of study; Proceedings of interaction

\section{RESUMO}

Objetivo: Avaliar os aspectos do ambiente de estudo e da interação, relacionados à permanência de graduandos e pós-graduandos em disciplinas semipresenciais da área da saúde. Métodos: Pesquisa de abordagem quantitativa, exploratória, que analisou os dados originados com base em um questionário validado, baseado nos modelos MAIS e IMPACT com 18 itens, organizados em uma escala que variou de zero (dificultou minha permanência na disciplina) a 10 (não dificultou minha permanência na disciplina). Foram convidados todos os 220 alunos concluintes das disciplinas de graduação e pós-graduação ofertadas na Faculdade de Ciências da Saúde da UnB, dos quais 148 (67,3\%) alunos aceitaram participar do estudo. Resultados: Todos os 18 itens (100\%) respondidos pelos graduandos e 17 (94,5\%) pelos pós-graduandos apresentaram médias superiores a sete, demonstrando que o uso do ambiente virtual, a flexibilidade do tempo e do espaço, os custos envolvidos, o uso das ferramentas computacionais e aos procedimentos de interação, foram bem avaliados. Conclusão: Graduandos e pós-graduandos consideraram que os quesitos relacionados ao ambiente de estudo e aos procedimentos de interação facilitaram a permanência nas disciplinas.

Descritores: Educação a distância; Educação superior; Evasão escolar; Ambiente de estudo; Procedimentos de interação

\section{RESUMEN}

Objetivo: Evaluar los aspectos del ambiente de estudio y de la interacción, relacionados a la permanencia de graduandos y postgraduandos en disciplinas semi presenciales del área de la salud. Métodos: Investigación de abordaje cuantitativo, exploratorio, en el que se analizó los datos originados con base en un cuestionario validado, fundamentado en los modelos MAIS e IMPACT con 18 items, organizados en una escala que varió de cero (dificultó mi permanencia en la disciplina) a 10 (no dificultó mi permanencia en la disciplina). Fueron invitados los 220 alumnos que concluyeron las disciplinas de pregrado y postgrado ofertadas en la Faculdad de Ciencias de la Salud de la UnB, de los cuales 148 (67,3\%) alumnos aceptaron participar en el estudio. Resultados: Todos los 18 items (100\%) respondidos por los graduandos y 17 (94,5\%) postgraduandos presentaron promedios superiores a siete, demostrando que el uso del ambiente virtual, la flexibilidad del tiempo y del espacio, los costos involucrados, el uso de las herramientas informáticas y los procedimientos de interacción, fueron bien evaluados. Conclusión: Graduandos y postgraduandos consideraron que los requisitos relacionados al ambiente de estudio y a los procedimientos de interacción facilitaron la permanencia en las disciplinas.

Descriptores: Educación a distancia; Educación superior; Abandono de los estudiantes; Ambiente de estúdio; Procedimientos de interacción

* Article extracted from Master dissertation "Evaluation of Health Promotion Education in undergraduate and graduate classes in health area at the University of Brasilia", presented to the Nursing Graduate Program at the University of Brasilia - UNB - Brasilia (DF), Brazil

${ }^{1}$ Master's Degree, Researcher at the University of Brasilia and Professor of Brasilia Universitary Center. Brasilia(DF), Brazil.

2 Academic, Teaching licence in Computer Science, Federal University of Paraiba - UFPA - Joao Pessoa (PB). Brazil.

${ }^{3}$ PhD, Full Professor, University of Brasilia - UnB - Brasilia (DF), Brazil. 


\section{INTRODUCTION}

The emergence of new Information and Communication Technologies (ICT) is transforming the paradigm of teaching and learning and the relationship between individuals, work and society, breaking down barriers imposed by time and space. These technological innovations have enabled individuals to access information, which keeps them permanently and continuously updated, aiding the effectively and actively exercise of citizenship, in an increasingly globalized world ${ }^{(1)}$.

In this perspective, the use of technology in education appears as an increasingly present reality ${ }^{(2)}$. In health area, there has been a rapid growth in Distance Education (DE), both in undergraduate and graduate learning, especially in nursing. This expansion has been driven by ICT, which have enabled the use of computational tools that facilitate the teaching and learning process ${ }^{(3,4)}$.

In $\mathrm{DE}$, the educational process is made possible by ICT in a Virtual Learning Environment (VLE) accessed via the Internet, which has the function of covering instructional interfaces and encourage interaction between learners ${ }^{(2)}$. Thus, the VLE can be considered a virtual classroom, where the use of communication tools such as the library, electronic mail, chat rooms and discussion forums, promote interaction and ensure that activities are developed at the most suitable pace, time and location to the participant ${ }^{(5)}$.

In this context, the Study Center in Education, Health Promotion and Inclusive Projects (NESPROM) has been coordinating the provision of undergraduate and graduate students at the University of Brasilia (UNB). The experience has been organized through standard electronic portfolios inserted to virtual learning environments, called Moodle-folios. Its use has been becoming points of collective meetings that allow processes and products recording, results from the activities developed in the classes.

The choice of Moodle VLE is justified by the fact that it is an open and free learning source platform, which allows the integration of multiple media and presentation of information in different formats for the student. It also allows interaction between users through synchronous tools (real-time activities, e.g. chat) and asynchronous (activities that do not occur concomitantly, e.g. discussion forum $)^{(2,6)}$.

Given the above, there is a need for knowledge production on instructional systems that promote systematic assessments of such process, providing enhancers subsidies, being responsible for providing feedbacks to ensure constant improvement of qualification ${ }^{(7,8)}$.

In this sense, two models of qualification assessment should be highlighted: the Integrated and Summative
Assessment Model (ISAM) that addresses environmental variables and the process of evaluating the results of training and the Model of Assessment of the Impact in Work Training (MAIWT) that investigates several predictive variables of efficiency and effectiveness of training, analyzing the relationship between the levels of reaction, learning and impact. Both models have supported the assessment of aspects that facilitate the student's stay in the educational process ${ }^{(9,10)}$.

Among the factors that have been associated with the permanence of students enrolled in DE, are highlighted: satisfaction with the environment of class/course (available services, fast service to the needs of the student and others); skill and competence related to the use of technological tools (forum, chat, messaging, email, etc..), the learner's social context (family, colleagues, employer, work and others) and the interaction between the actors involved in the educational process ${ }^{(11,12)}$.

In this scenario, this study aimed to assess the environmental aspects of the study and the interaction procedures related to the permanence of undergraduate and graduate students in semipresential classes in health area.

\section{METHODS}

This study consisted of a research of quantitative exploratory approach, in which data was collected between January and February 2011.

The research was conducted in undergraduate classes, Health Promotion 2 (HP2), Advanced Topics in Health Promotion 1 (ATHP), Methodology of Health Research (MHR) in the Certificate of Education and Health Promotion course (CEHP) and in the class of graduate stricto sensus Educational Practices in Health Sciences (EPHS), all coordinated by NESPROM and offered to students of the Faculty of Health Sciences at UNB.

The study was submitted to the Ethics Committee in Research of the Faculty of Health Sciences at UNB and approved in December 2010, Protocol 137/10, based on Resolution 196/96 of the National Health Council, which deals with the directives and standards regulating research involving humans.

The inclusion criteria used in the sample were as follows: all undergraduate students, certificate, master's and $\mathrm{PhD}$, both genders, duly enrolled, who completed the evaluated course or classes in the second semester of 2010 and who agreed to voluntarily participate in the research by signing a Consent Form. As an exclusion criterion, the refusal to participate.

Then, the primary data was collected through a validated questionnaire ${ }^{(9)}$, elaborated based on the models ISAM and MAIWT. The instrument consisted of two stages, with the purpose of collecting sociodemographic 
data (stage 1) and investigating students' reactions to the study environment; and interaction procedures (step 2) using a scale consisting of 18 items, 11 points Likert scale, ranging from zero (hindered my permanence in the course/class) to 10 (did not hinder my permanence in the course/class).

The disciplines ATHP, MHR and HP2 had, respectively, $44.34 \%, 84.62 \%$ and $95.65 \%$ of the students sampled, which represented $56.34 \%$ (80) of the total number of undergraduate senior students. In the graduate course CEHP and EPHS, 68\% and 96.23\% of graduating students participated in the research, representing $87.18 \%$ of the total number of graduate students. Thus, out of the 220 senior students, 148 $(67.27 \%)$ comprised the sample. Only eight (3.5\%) enrolled students dropped out of the classes/course.

In this study a quantitative data analysis was applied to students' personal data (age, gender, educational level, number of classes in the semester and others) and numerical responses of the participants to scale. For composing the database, five missing data were excluded and ten univariate outliers ( $\mathrm{Z}$ scores equal to or greater than -3.29 or +3.29 ).

Statistical analysis was conducted by descriptive analysis (means, standard deviations, and percentages), by calculating the difference between the means we used the nonparametric Mann-Whitney test, after verified the non-normal distributions of the frequency (Kolmogorov-Smirnov test). The chi-square and Fisher's exact test were used to assess the relationship between independent categorical variables. We adopted a significance level of $5 \%$. For the implementation of the statistical analysis, we used SPSS Statistical Software ${ }^{\circledR}$ (Statistical Package for Social Sciences), version 17.0.

\section{RESULTS}

Data in Table 1 shows the students sociodemographic characteristics, and divide them into two groups. The first group was composed by undergraduate students (US) of ATHP, MHR and HP2 classes, and the second group by graduate students (GS) EPHS class and CEHP course. It was also analyzed whether there were differences between characteristics among US and GS groups, which showed statistical significance values.

According to Table 1, the participants of the classes had the following characteristics: $56(70 \%)$ and 55 $(80.9 \%)$ were females, respectively in US and GS education, presenting no significant difference $(\mathrm{p}>0.05)$. Regarding the age of those involved, it was observed a difference between undergraduates and graduate students $(\mathrm{p}<0.05)$, predominantly in US age group between 18 and 23 years, $64(80 \%)$, and in education of GS within the age group between 24 and 34 years, 34 (50\%).
Table 1. Sociodemographic characteristics of research participants. Brasilia, Distrito Federal, 2011. $\mathrm{n}=148$

\begin{tabular}{|c|c|c|c|c|}
\hline \multirow[t]{2}{*}{ Variables } & $\begin{array}{c}\text { Total } \\
\mathrm{n}=148\end{array}$ & $\begin{array}{c}\text { US } \\
\mathrm{n}=80\end{array}$ & $\begin{array}{c}\text { GS } \\
\mathrm{n}=68\end{array}$ & \multirow{2}{*}{$\begin{array}{c}\mathrm{p} \\
\text { value }\end{array}$} \\
\hline & $\mathrm{n}(\%)$ & $\mathrm{n}(\%)$ & $\mathrm{n}(\%)$ & \\
\hline Age groups & & & & $0.001^{\mathrm{a}}$ \\
\hline 18 to 23 years & $70(47.3)$ & $64(80)$ & $6(8.8)$ & \\
\hline 24 to 34 years & $48(32.4)$ & $14(17.5)$ & $34(50)$ & \\
\hline 35 to 45 years & $21(14.2)$ & $2(2.5)$ & $19(27.9)$ & \\
\hline 46 to 56 years & $8(5.4)$ & $0(0)$ & $8(11.8)$ & \\
\hline 57 to 67 years & $1(0.7)$ & $0(0)$ & $1(1.5)$ & \\
\hline Gender & & & & $0.182^{\mathrm{b}}$ \\
\hline Female & $111(75.0)$ & $56(70)$ & $55(80.9)$ & \\
\hline Male & $37(25.0)$ & $24(30)$ & 13(19.1) & \\
\hline Employed & & & & $0.001^{\mathrm{b}}$ \\
\hline No & $49(33.1)$ & $42(52.5)$ & $7(10.3)$ & \\
\hline Yes & $99(66.9)$ & $38(47.5)$ & 61(89.7) & \\
\hline Live & & & & $0.002^{a}$ \\
\hline With friends & $4(2.7)$ & $2(2.5)$ & $2(2.94)$ & \\
\hline With family & $128(86.5)$ & $76(95)$ & $52(76.5)$ & \\
\hline Alone & $16(10.8)$ & $2(2.5)$ & $14(20.6)$ & \\
\hline Housing & & & & $0.504^{a}$ \\
\hline Rent & $39(26.4)$ & $18(22.5)$ & $21(30.9)$ & \\
\hline Cortesy of UnB & $2(1.4)$ & $1(1.25)$ & $1(1.5)$ & \\
\hline Own & $107(72.3)$ & $61(76.25)$ & $46(67.6)$ & \\
\hline Marital status & & & & $0.001^{a}$ \\
\hline With partner & $40(27.0)$ & $12(15)$ & $28(41.2)$ & \\
\hline $\begin{array}{l}\text { divorced/ } \\
\text { separated }\end{array}$ & $8(5.4)$ & $0(0)$ & $8(11.8)$ & \\
\hline Single & $100(67.6)$ & $68(85)$ & $32(47.1)$ & \\
\hline Have Children & & & & $0.001^{\mathrm{b}}$ \\
\hline No & $123(83.1)$ & $78(97.5)$ & $45(66.2)$ & \\
\hline Yes & $25(16.9)$ & $2(2.5)$ & $23(33.8)$ & \\
\hline $\begin{array}{l}\text { Family income } \\
\left(\mathbf{M W}^{*}\right)\end{array}$ & & & & $0.590^{\mathrm{a}}$ \\
\hline Between 1 and 2 & $4(2.7)$ & $3(3.75)$ & $1(1.5)$ & \\
\hline Between 3 and 4 & $5(3.4)$ & $2(2.5)$ & $3(4.4)$ & \\
\hline Between 5 and 6 & $21(14.2)$ & $9(11.25)$ & $12(17.6)$ & \\
\hline Between 7 and 8 & $19(12.8)$ & $12(15)$ & $7(10.3)$ & \\
\hline More than 8 & $99(66.9)$ & $54(67.5)$ & $45(66.2)$ & \\
\hline Own a computer & & & & $0.500^{\mathrm{b}}$ \\
\hline No & $2(1.4)$ & $2(2.5)$ & $0(0)$ & \\
\hline Yes & $146(98.6)$ & $78(97.5)$ & $68(100)$ & \\
\hline
\end{tabular}

${ }^{\mathrm{a}}$ Chi-square test; ${ }^{\mathrm{b}}$ Fisher's exact test; MW: Minimum Wage 
Significant differences were observed in the following variables: employed, live, marital status and children. In the first variable, $47.5 \%$ of US and $89.7 \%$ of GS reported to be employed. The second variable, living with family was more frequent among US and GS, 95\% and $76.5 \%$ respectively, but there was a higher percentage of students living alone among the GS. With regard to marital status, there was a predominance of singles in both groups, but $41.2 \%$ of GS and only $15 \%$ US live with a partner(a). Regarding the variable have children, $33.8 \%$ of GS and $2.5 \%$ of US had children.
No differences were observed between US and GS in the variables: house, family income and own a computer, predominantly house owners ( $72.3 \%$ of students), family income greater than eight times the minimum wage $(66.9 \%$ of students) and own a computer in $98.6 \%$ of students.

Responses from 148 students to 18 items in the questionnaire that investigated students' reactions to the study environment and interaction procedures, data described in Table 2, presents mean and standard deviation of all items, according to the total students and the academic level (US and GS).

Table 2. Difference between groups separated based on the Reaction Scale of the Study Environment and Interaction Procedures. Brasilia, Distrito Federal, 2011. $\mathrm{n}=148$

\begin{tabular}{|c|c|c|c|c|c|}
\hline Itens & Variables & $\begin{array}{c}\text { Total } \\
\mathrm{n}=148 \\
\text { Mean } \pm \text { SD }\end{array}$ & $\begin{array}{c}\text { US } \\
n=80 \\
\text { Mean } \pm \text { SD }\end{array}$ & $\begin{array}{c}\text { GS } \\
n=60 \\
\text { Mean } \pm S D\end{array}$ & $\begin{array}{c}\mathrm{p} \\
\text { value }\end{array}$ \\
\hline 01 & Computer use in different activities of the course/class on my daily basis & $8,97 \pm 1,63$ & $8,85 \pm 1,70$ & $9,11 \pm 1,56$ & 0,215 \\
\hline 02 & Conciliation of the class with other study activities & $8,03 \pm 2,19$ & $8,50 \pm 1,76$ & $7,52 \pm 2,49$ & 0,019 \\
\hline 03 & Conciliation of the class with my family commitments & $7,73 \pm 2,56$ & $8,18 \pm 2,37$ & $7,24 \pm 2,68$ & 0,006 \\
\hline 04 & Problems related to my health & $7,96 \pm 2,90$ & $7,95 \pm 2,91$ & $7,97 \pm 2,91$ & 0,807 \\
\hline 05 & Availability of computers during the time I have to study & $8,86 \pm 1,72$ & $8,89 \pm 1,66$ & $8,83 \pm 1,79$ & 0,981 \\
\hline 06 & Financial cost to print course materials & $8,49 \pm 2,67$ & $8,04 \pm 2,95$ & $8,97 \pm 2,26$ & 0,009 \\
\hline 07 & Financial cost for computer maintenance & $8,82 \pm 1,91$ & $8,48 \pm 2,27$ & $9,18 \pm 1,36$ & 0,140 \\
\hline 08 & Financial cost for Internet access & $8,99 \pm 1,59$ & $8,73 \pm 1,79$ & $9,25 \pm 1,32$ & 0,052 \\
\hline 09 & Conciliation of the class with my professional activities & $7,32 \pm 2,76$ & $8,09 \pm 2,44$ & $6,47 \pm 2,85$ & 0,001 \\
\hline 10 & New professional activity emerged when I was taking the class & $7,37 \pm 3,16$ & $7,66 \pm 3,05$ & $7,06 \pm 3,27$ & 0,338 \\
\hline 11 & Access to the course on the Internet with the proposed regularity & $7,61 \pm 2,73$ & $7,73 \pm 2,72$ & $7,49 \pm 2,76$ & 0,610 \\
\hline 12 & Study the content of the class with the proposed regularity & $7,67 \pm 2.53$ & $7,70 \pm 2,56$ & $7,63 \pm 2,51$ & 0,810 \\
\hline 13 & Quality of internet connection & $7,77 \pm 2,80$ & $7,58 \pm 2,90$ & $7,97 \pm 2,68$ & 0,297 \\
\hline 14 & Amount of administrative messages sent & $8,19 \pm 2,59$ & $7,92 \pm 2,84$ & $8,49 \pm 2,26$ & 0,139 \\
\hline 15 & Reading volume on the computer screen & $7,62 \pm 2,86$ & $7,49 \pm 3,00$ & $7,76 \pm 2,72$ & 0,630 \\
\hline 16 & Used messaging to communicate with tutors and colleagues & $7,59 \pm 2,90$ & $7,05 \pm 3,31$ & $8,18 \pm 2,27$ & 0,070 \\
\hline 17 & Used chat to communicate with tutors and peers & $7,04 \pm 3,22$ & $6,84 \pm 3,46$ & $7,25 \pm 2,95$ & 0,736 \\
\hline 18 & Used forum to communicate with tutors and peers & $7,82 \pm 2,90$ & $7,03 \pm 3,28$ & $8,68 \pm 2,13$ & 0,002 \\
\hline
\end{tabular}

\section{DISCUSSION}

The results presented in Table 1 show that although there were significant differences in the variables: age groups, employed, live, marital status and have children, there are important similarities between the US and GS. It was observed, therefore, higher frequencies, in both academic levels, of female students, youth aged between 18 to 34 years, singles, those who live in their own home, with their family, those who have a computer and those with family income greater than eight times the minimum wage. Being employed has also been a frequent characteristic, although there was a higher percentage among graduate students.

The fact of being outstanding in the sample, in both groups, students with higher family income and who owned a computer, may have facilitated the permanence in the classes and course assessed. However, it may also indicate potential obstacles to access distance education, among those who did not owned a computer or with low family income. 
In a research conducted at the Federal University of São Carlos (UFSCar), discontinuance of nursing students enrolled in Distance Education was related to lack of access to the computer, being female and the lack of time, since, among women, house work and motherhood reduce the time that would be devoted to studies ${ }^{(6)}$.

The results identified in this study are similar to findings reported in a study that characterized the profile of Brazilian university students ${ }^{(13)}$, indicating that the number of women is superior than men by $12 \%$, representing the majority in $69 \%$ of the areas of knowledge; most of the students work and have a family income between three to ten minimum wages.

Regarding the study environment and interaction procedure, the 18 items described in Table 2, showed mean equal to or greater than seven (facilitated permanence) in both groups, the only exception was the item nine, whose score was 6.47 among graduate students. The standard deviation showed the lowest value in item eight (1.59) and the highest value in item 17 (3.22) when considering the data from the total of students, in items one (1.61) and 17 (3.46) when considered the group composed by US; and in item eight (1.36) and 10 (3.09) when considered the group consisting of GS. The standard deviations presented on most items can be considered high, indicating a variability in the responses of the participants.

Study ${ }^{(9)}$ performed with senior students of a Distance Learning Course, which showed a drop out of $34 \%$, used the same instrument adopted in this research to assess the reaction to the study environment and interaction procedures between students of $\mathrm{DE}$, having identified means above seven in 100\% of participants. This study also showed means above seven in all items between the undergraduates and 17 (94.5\%) among graduate students, indicating that the study environment and interaction facilitated the permanence of students sampled in the tested classes.

There were no statistically significant differences $(\mathrm{p}<0.05)$ between the means presented by GS and US on 11 items evaluated. However, there were minor differences, but significant in items two $(\mathrm{d}=0.40)$; three $(d=0.27)$, six $(d=0.34)$ and $18(d=0.43)$. A moderate difference was observed in item nine $(\mathrm{d}=0.53)$.

Therefore, although there are significant differences between the means, originated on the basis of undergraduate and graduate students, the effects of these were not significant, indicating that both groups remained in the classes and course for similar reasons. Among the main reasons are: financial cost to access the Internet, print material and perform computer maintenance, use computer in different activities of the class/course in everyday life; computer availability, quality of administrative messages; conciliate class with other education activities and the use of forum to communicate with tutors and colleagues.

In a virtual environment, the educator must maintain an active dialogue with their students through chats, discussion forums and interactive activities, attracting attention. Questioning and challenging the resolution capability of students as well as the fast, however, aware and responsible decision making are also pedagogical strategies that can stimulate the process of teaching and learning ${ }^{(12)}$.

Such statements corroborate the identified results in items that address the interaction and study environment. All presented means above seven, therefore, considered as facilitators, such as: access to the course on the Internet with proposed regularity, mean 7.73 (US) and 7.49 (GS), $\mathrm{p}>0.05$; study the content with the proposed regularity, mean 7.70 (US) and 7.69 (GS), p>0.05; quality of the Internet connection, mean 7.58 (US) and 7.97 (GS), $\mathrm{p}>0.05$, the amount of administrative messages sent, mean 7.92 (US) and 8.49 (GS), p>0.05; reading volume on the computer screen, mean 7.49 (US) and $776(\mathrm{GS}), \mathrm{p}>0.05$, used messaging to communicate with tutors and colleagues, mean 7.05 (US) and 8.18 (GS), $\mathrm{p}>0.05$, used chat to communicate with tutors and colleagues, mean 6.84 (US) and 7.25 (GS), p>0.05 and used forum to communicate with tutors and peers, mean 7.03 (US) and 8.68 (GS), $\mathrm{p}<0.05$.

Thus, in distance education, flexibility of time and space that hybrid courses provide teachers and students impact the learning process, adding gains in students' education, such as: the development of autonomy, discipline and, above all, skills in the use of ICT resources $^{(14)}$. However, this freedom has been listed as one of the causes of dropouts among students enrolled in distance learning ${ }^{(15)}$.

DE may modify how the student understands the study, considering time and space, one can reflect on the following responsibilities: discipline, organization, persistence, commitment, and other aspects that can influence student performance ${ }^{(15)}$. Moreover, the target audience of courses in this modality is usually graduated adults who work and have insufficient time for studies ${ }^{(16)}$.

In this study, factors associated with time and space were analyzed using the following variables: Conciliation of the class with other study activities, mean 8.50 (US) and 7.52 (GS), $\mathrm{p}<0.05$; conciliation of the class with family commitments, mean 8.18 (US) and 7.24 (GS), $\mathrm{p}<0.05$; availability of computers during the time I have to study, mean 8.89 (US) and 8.83 (GS), p>0.05 and conciliation of class with professional activities, mean 8.09 (US) and 6.47 (GS), $\mathrm{p}<0.05$. These results indicate that graduate students have lower means than undergraduates, although in both groups, most of the variables have shown a mean 
above seven. Therefore, these means were considered as facilitators of permanence in the classes.

Another important aspect relates to the described costs in the variables: financial cost to print course materials, mean 8.04 (US) and 8.97 (GS), p<0.05; financial cost for computer maintenance, mean 8.48 (US) and 9.18 (GS), $\mathrm{p}>0.05$ and financial cost to access the Internet, mean 8.73 (US) and 9.25 (GS), p>0.05. It is observed that in both groups the mean values were greater than eight, indicating that the costs have contributed for students to continue studying.

Internet access and computer use are growing in Brazil and worldwide, enabling thus exceptional educational resources. Nevertheless, they are still not available to everyone, limiting the opportunities for individuals and social groups that have not yet developed the skills and abilities needed, or simply do not have the appropriate resources. In Brazil, approximately $50 \%$ of the population have never used the Internet, and among those who have already done so, many do not have regular access or cannot properly understand the information. Conversely, determining the digital exclusion or inclusion simply by having a computer at home with internet connection is a simplification, a superficial assessment of the issue ${ }^{(17)}$.

Based on the what has been exposed, the present study reveals, from the perception of undergraduate and graduate students, aspects capable of promoting a facilitator environment of permanence of students enrolled in distance learning.

\section{REFERENCES}

1. Rodrigues RC, Peres HH. [A panorama of Brazil's online nursing teaching]. Rev Esc Enferm USP. 2008; 42(2): 298304. Portuguese.

2. Rangel EM, Mendes IA, Cárnio EC, Alves LM, Crispim JA, Mazzo A, et al. Evaluation by nursing students in virtual learning environments for teaching endocrine physiology. Acta Paul Enferm. 2011; 24(3): 327-33.

3. Cogo AL, Silveira DT, Pedro EN, Tanaka RY, Catalan VM. Aprendizagem de sinais vitais utilizando objetos educacionais digitais: opinião de estudantes de enfermagem. Rev Gaúcha Enferm. 2010; 31(3): 435-41.

4. Barbosa SF, Marin HF. Web-based simulation: a tool for teaching critical care nursing. Rev Latinoam Enferm. 2009; 17(1): 7-13.

5. Mezzari A. [The use of Problem-Based Learning (PBL) as reinforcement for students using the moodle learning environment]. Rev Bras Educ Méd. 2011; 35(1): 114-21. Portuguese.

6. Aparecida Jacomini R, Piai TH, Morales de Figueiredo R. [Evaluation of a distant learning course on hepatitis C]. Invest Educ Enferm. 2008; 26(2 supl): 98-104. Portuguese.

7. Varanda RC, Zerbini T, Abbad G. [Construction and validation of graphic interface reactions scale for distance learning courses]. Psicol Teor Pesqui. 2010; 26(2): 371-80. Portuguese.

8. Zerbini T, Abbad G. [Learning strategies in distance course: Validation of a scale]. Psico USF. 2008; 13(2): 177-87. Portuguese.

9. Zerbini T, Abbad G. Qualificação profissional a distância: ambiente de estudo e procedimentos de interação - validação de uma escala. Análise. 2008; 19(1): 148-72.

\section{CONCLUSION}

The study environment and interaction procedures were assessed through 18 items that facilitated or hindered the permanence in the classes and course evaluated. The responses of all students, represented by means greater than seven, indicated that all items assessed contributed to the permanence.

Another important finding is due to the fact there were not significant differences between academic levels on most items investigated. However, in five items, the differences were statistically significant, but did not show great effects, indicating that the differences were not significant. Therefore, undergraduates and graduate students perceive and remain in classes for similar reasons.

Upon the foregoing, it can be considered as facilitating aspects of permanence: the use of computers in different activities of the course/class in daily life; conciliation of the class with other study activities and family commitments; the availability of computer; the financial cost to print the course material, computer maintenance and access to the internet; conciliation of professional activities; access the course on the Internet and the study content with the proposed regularity; the quality of the internet connection and administrative messages sent, the amount of reading on the computer screen, and used messages, forums and chats for communication with tutors and colleagues.

10. Zerbini T, Abbad G. [Distance Education: training transfer evaluation]. Paidéia (Ribeirão Preto). 2010; 20(47): 313-23. Portuguese.

11. Nair SP. Towards understanding the successful learner: a case study of IGNOU. Turkish Online J Distance Educ. 2012; 13(2): 322-35.

12. Favero RV, Franco SR. Um estudo sobre a permanência e a evasão na educação a distância. RENOTE Rev Novas Tecnol Educ. 2006; 4(2): 1-10.

13. Osório FL, Crippa JA, Loureiro S. [Self statements during public speaking scale (SSPS): cross-cultural adaptation for Brazilian Portuguese and internal consistency]. Rev Psiquiatr Clín. 2008; 35(6): 207-11. Portuguese.

14. Bertolin JC, Marchi AC. [Instruments for the evaluation of semipresential courses: a proposal based on systems of indicators]. Avaliação. 2010; 15(3): 131-46. Portuguese.

15. Carvalho AB. Os múltiplos papéis do professor em educação a distância: uma abordagem centrada na aprendizagem. In: $18^{\circ}$ Encontro de Pesquisa Educacional do Norte e Nordeste - EPENN; 2007 Julho 1- 4; Maceió.

16. Abbad G, Carvalho RS, Zerbini T. [Evasion from internetbased: exploring explanatory variables]. RAE Eletron [Internet]. 2006 [cited 2012 Out 20]; 5(2): [about 26p]. Portuguese.

17. Garbin HB, Guilam MC, Pereira Neto AF. [Internet and health promotion: a tool for the development of individual and social skills]. Physis. 2012; 22(1): 347-63. 